\title{
POLA STRATEGI KOMUNIKASI ORANG TUA TERHADAP ANAK PADA ERA DIGITALISASI (STUDI: WARGA MALINJO PASAR MINGGU JAKARTA SELATAN)
}

\author{
Djudjur Luciana Radjagukguk \\ Universitas Nasional (UNAS) Jakarta \\ Email: djudjurluciana01@gmail.com
}

\begin{abstract}
Supervision of children is very important to be realized because of the development of information in the digitalization era, in addition, children must be able to choose the appropriate information according to the stage of development. In the education process of era digital, the role of parents must know the ways of the child's ability to respond and see themselves positively in use digital devices properly. Therefore, the family is the first and foremost educational institution for children. Because the parents are known and receive early education from the home environment. Guidance, attention and affection between parents and their children, is a powerful basis for psychological growth and development, social and religious values in children. The purpose of this research was to know and describe the pattern of communication strategies of parents to children in the era of digitalization. The method used in the form of observation and in-depth interviews with teenagers and parents. The results showed that the development of the digital era that is increasingly developing influence on the development of children's psychology will have a negative impact on social education as well as the adverse effects arising from the development of digitalization. Parents also should not close meeting of the development of the digital era for children because behind the development of the digital era there are many positive things that can be achieved. At this point, the role of parents in educating children in the digital era is needed to sort out the positive and negative aspects of technological development besides the hardest obstacle for parents is creating "Family atmosphere" who are close to the way often chatting, playing and hearing the one's story of children. And there must be a commitment between family members in the use of gadgets in the digitalization era.
\end{abstract}

Keywords: Communication Strategy Pattern, The Era of Digitalization

\section{Abstrak}

Pengawasan kepada anak begitu penting diwujudkan karena perkembangan informasi pada era digitalisasi, di samping itu anak mampu memilah informasi yang sesuai dengan tahap perkembangannya. Dalam proses pendidikan era digital peranan orang tua harus mengetahui cara-cara kemampuan anak untuk menyikapi serta memandang dirinya secara positif dalam menggunakan perangkat digital secara benar. Oleh karena itu, keluarga adalah lembaga pendidikan yang pertama serta utama untuk anak. Karena kedua orang tua yang pertama dikenal serta menerima pendidikan awal dari lingkungan rumah. Bimbingan, perhatian, serta kasih sayang yang terjalin antara kedua orang tua bersama anak-anaknya, adalah basis yang mujarab bagi tumbuh kembang psikis serta nilai-nilai sosial dan religius pada diri anak. Tujuan penelitian ini adalah untuk mengetahui dan memaparkan pola strategi komunikasi orang tua terhadap anak pada era digitailsasi. Metode yang digunakan berupa observasi dan wawancara mendalam terhadap remaja dan oarngtua. Hasil penelitian menunjukkan bahwa perkembangan era digital yang semakin berkembang berpengaruh terhadap perkembangan psikologi anak akan berdampak negatif dalam pendidikan sosial serta efek buruk yang ditimbulkan dari perkembangan digitalisasi. Orang tua juga tidak boleh menutup rapat perkembangan era digital bagi anak dikarenakan dibalik perkembangan era digital tersebut ada banyak hal positif yang dapat diraih. Pada titik inilah peran orang tua dalam mendidik anak dalam era digital sangat dibutuhkan guna memilih baik hal positif ataupun negatif dari perkembangan teknologi disamping kendala terberat bagi 
orang tua yaitu menciptakan "suasana keluarga" yang dekat dengan cara sering mengobrol, bermain dan mendengar curhatan anak-anak. Serta harus ada komitmen antar anggota keluarga dalam penggunaan gadget di era digitalisasi.

Kata kunci : Pola Strategi Komunikasi, Era Digitalisasi.

\section{Pendahuluan}

Perkembangan teknologi informasi dan komunikasi merupakan salah satu dampak dari perkembangan zaman yang kian harinya mengalami kemajuan yang pesat. Banyak hal yang melatarbelakangi perkembangan teknologi informasi dan komunikasi tesebut, salah satunya adalah adanya kebutuhan umat manusia yang semakin harinya dituntut untuk dapat menjalankan segala sesuatunya dengan lebih mudah dan efektif. Begitu pula perkembangan teknologi dan informasi di Indonesia berjalan sangat dinamis (Cholik, 2017). Pengawasan kepada anak begitu penting dalam mewujudkan banyak informasi yang masuk, diwajibkan dapat memilih informasi yang cocok serta sesuai tahap informasi yang masuk dan harus bisa memilah informasi yang cocok serta sesuai dengan tumbuh kembangnya (Ramadhani \& Ritonga, 2019). Sehingga, untuk proses pendidikan era digital peran orang tua wajib memperhatikan metode untuk mengetahui kemampuan anak dalam menyikapi serta memandang dirinya secara positif supaya menggunakan perangkat digital secara benar. Keluarga adalah lembaga pendidikan yang pertama serta utama bagi anak Bimbingan, perhatian, serta kasih sayang yang terjalin antara kedua orang tua bersama anak-anaknya, adalah basis yang mujarab untuk tumbuh kembang psikis serta nilai-nilai sosial serta religius pada diri anak.

Melihat perkembangan era digital yang semakin berkembang di dunia saat ini, yang tentunya berpengaruh terhadap perkembangan psikologi anak sehingga keluarga adalah benteng utama dalam melakukan pendidikan. Baik efek buruk yang ditimbulkan dari perkembangan era digital tersebut. Orang tua tidak boleh menutup rapat perkembangan era digital untuk anak dikarenakan dibalik perkembangan era digital tersebut ada banyak hal positif yang dapat diraih, pada titik inilah peran orang tua untuk mendidik anak dalam era digital sangat dibutuhkan untuk memilih baik positif maupun negatif dari perkembangan teknologi tersebut.

Sehingga perkembangan teknologi yang ada saat ini, menjadikan kendala terberat bagi orang tua dalam mendidik anak-anak terlebih jika melihat berbagai kondisi saat ini seperti anak remaja sekarang ini lebih memilih menghabiskan waktu dengan media sosial dibandingkan dengan membaca pengetahuan lainnya. Serta pola perilaku anak remaja saat ini lebih kebarat-baratan dan bahkan tradisi ataupun hal-hal yang menjadi budaya di daerah semakin lama semakin terkikis serta budaya dalam kehidupan sehari-harinya lebih mengikut ke barat-baratan tanpa memperhatikan norma-norma yang ada baik norma sosial maupun agama.

Salah satu di sudut kota Jakarta, Kecamatan Pasar Minggu, Jakarta Selatan berdirilah suatu tempat bagi remaja untuk dapat berkumpul dan bersosialisasi. Ruang Publik Terpadu Ramah Anak yang biasa disebut dengan RPTRA Malinjo. Para remaja bahkan dari usia balita, anak-anak, remaja bahkan kaum ibu dapat melakukan pertemuan di RPTRA ini. Tentu saja, ini merupakan sarana yang baik bagi setiap orang untuk bisa bermain, berdiskusi bahkan melakukan kegiatan sosial terlebih pada anak remaja yang sekarang ini kegiatan mereka lebih banyak dengan handpone.

Peran orang tua dalam mendidik anak dimulai dari sejak dini dan sudah menjadi kewajiban mendampingi anak-anak ke arah yang lebih baik. Saat ini, dibutuhkan jika orang tua seharusnya memiliki ilmu pengetahuan lebih dulu mengenai bermedia sosial, sehingga tidak lebih pandai anak satu tahun memainkan handphone yang dimiliki orang tuanya. Orangtua juga mengarahkan satu sarana dimana anak-anak dapat belajar dan bermain tanpa harus berganung dengan alat digital. Dalam proses pendidikan diera digital peran orang tua harus mencermati cara-cara mengetahui kemampuan anak untuk menyikapi 
dan memandang dirinya secara positif agar menggunakan perangkat digital dengan baik (Winarno, 2012).

Dijelaskan secara rinci dalam Artikel yang berjudul: "Peran Orang Tua dalam Mendidik Anak Di Era Digital” https://www.duniabelajaranak.id/peran-orang-tua-dalammendidik-anak-di-era-digital/ sangat diharapkan anak-anak bisa menggunakan teknologi dengan bijak, komunikasi antara orang tua serta anak perlu dijaga. Hal ini sangat dibutuhkan supaya orang tua dapat memberikan hal-hal yang perlu dijadikan "warning" untuk anak, seperti pengelolaan waktu penggunaan gadget.

Orang tua satu yakni basis utamanya ialah karakter yang dimaksud karakter merupakan metode berpikir serta berperilaku yang dijadikan ciri khas tiap individu dalam hidup serta bekerjasama, baik dalam lingkup keluarga, masyarakat serta negara. Individu yang berkarakter baik merupakan individu yang mampu membuat keputusan serta siap mempertanggungjawabkan dampak dari keputusan yang telah dibuat (Ihsan, 2005). Implikasi Pendidikan karakter dalam pelaksanaannya membutuhkan support dari berbagai pihak, bukan hanya dari guru atau pihak Sekolah tetapi juga keluarga serta lingkungan keluarga. Dalam pendidikan keluarga yang wajib diperhatikan, ketika menggunakan perangkat digital. Perangkat-perangkat digital itu, antara lain TV, komputer, ponsel cerdas, komputer tablet dan lain-lain. Karena dapat menyebabkan dampak yang buruk atau baik untuk anak. (Shin, 2014).

Suatu pola strategi komunikasi yang jitu sangat dibutuhkan bagi orang tua agar dapat berperan aktif dalam mengawasi dan mendidik anak-anaknya. Proses komunikasi yang terjain di dalam keluarga tidaklah berjalan dengan sederhana melainkan melalui proses serta tahapan-tahapan komunikasi. Hal ini sepadan dengan prinsip-prinsip komunikasi yang sudah dirancang oleh beberapa ahli dengan berbagai latar belakang disiplin ilmu. Dalam proses komunikasi melibatkan berbagai macam pilihan yang meliputi aspek-aspek pesan serta aspek perilaku, pilihan perihal saluran komunikasi yang akan digunakan, karakteristik komunikator, hubungan antara komunikator serta khalayak, karakteristik khalayak, serta situasi dimana komunikasi terjalin.

\section{Metode Penelitian}

Pada penelitian ini, peniliti menggunakan pendekatan kualitatif sebagaimana pendapat (Rakhmat \& Surjaman, 2012) bahwa: "penelitian ilmiah pada dasarnya banyak bergantung pada cara peneliti mengumpulkan fakta." Metode yang dipilih saat meneliti topik apapun akan bergantung pada pertanyaan yang dicoba untuk dijawab dalam peneletian tersebut. Metode kualitatif, menurut (Bogdan \& Taylor, 1992), adalah prosedur penelitian yang menghasilkan data deskriptif berupa kata tertulis ataupun lisan dari orangorang serta perilaku yang dapat dicermati Pendekatan ini dapat diarahkan pada latar serta individu tersebut secara holistic (utuh). Sehingga, tidak diperboehkan mengisolasikan individu atau organisasi ke dalam variable atau hipotesis, tapi perlu memandangnya sebagai bagian dari suatu keutuhan.

Sementara itu, penelitian kualitatif adalah tradisi tertentu dalam ilmu pengetahuan sosial secara fundamental bergantung pada pengamatan pada manusia dalam kawasannya sendiri dan berhubungan dengan orang-orang tersebut dalam bahasa dan peristilahannya (Moleong, 2007). Peneliti menggunakan penelitian kualitatif karena dalam penelitian ini membahas mengenai pola strategi komunikasi orangtua pada anak di era digitalisasi. Semua kebenaran atau kejadian-kejadian sosial, serta pengamatan dilapangan peneliti lakukan baru kemudian menganalisisnya berdasarkan apa yang diamati. Sifat dari penelitian yang peniliti lakukan ini adalah deskriptif yang menyajikan data, menganalisis data dan mengintrepretasikan data (Narbuko \& Achmadi, 2005). Penelitian deskriptif hanya melukiskan keadaan obyek atau persoalannya. Selain itu tujuan dari penelitian deskriptif adalah untuk menggambarkan fakta-fakta dan realitas yang terdapat dilapangan mengenai pola strategi komunikasi orang tua pada anak di era digitalisas dengan subjek penelitian 
peneliti adalah orangtua di Kecamatan Pasar Minggu pada RPTRA Malinjo, Jakarta Selatan, sedangkan oybek penelitiannya adalah pola strategi komunikasi orangtua pada anak.

Tehnik pengumpulan data dilakukan melalui teknik wawancara yang didukung data primer maupun data sekunder. Wawancara berbentuk komunikasi verbal semacam percakapan yang bertujuan untuk memperoleh informasi dengan informan agar mendapatkan data lengkap dan mendalam. Peneliti memahami bahwa dalam jenis wawancara mendalam, wawancara yang dilakukan lebih bersifat informal, fleksibel, dan terbuka, sehingga memungkinkan adanya wawancara berulang pada narasumber yang sama dan dengan pertanyaan-pertanyaan yang lebih detail (Kriyantono \& Komunikasi, 2010). Key Informan tak hanya memberi keterangan tentang sesuatu kepada peneliti tetapi juga bisa memberi saran tentang sumber-sumber bukti lain yang mendukung serta menciptakan akses terhadap sumber yang bersangkutan. Analisis data dalam penelitian kualitatif, dilaksanakan bersamaan dengan proses pengumpulan data. Data kualitatif dapat berupa kata-kata atau kalimat-kalimat, baik yang diperoleh dari wawancara mendalam maupun observasi. Teknik analisis data diawali dengan mengorganisasikan data, memilah-milahnya menjadi satuan yang dapat dikelola, mensintesiskannya, traingulasi data, mencari dan menemukan pola, interpretasi data, menemukan apa yang penting dan apa yang dipelajari dan memutuskan apa yang dapat diceritakan kepada orang lain.

\section{Hasil dan Pembahasan}

Menurut Pace, Peterson, dan Burnett dalam Effendy (1984:35-36) menyatakan bahwa strategi komunikasi memiliki 3 (tiga) tujuan, yaitu

1. To secure understanding - memastikan pesan diterima oleh komunikan.

2. To establish acceptance - membina penerimaan pesan.

3. To motivate action - kegiatan yang dimotivasikan.

Pola adalah bentuk atau hubungan antara dua orang atau lebih dalam proses pengiriman dan penerimaan pesan. Sehinga dalam proses pengiriman dan penerimaan pesan bentuk perubahan dari perilaku sangat bervariasi, sesuai dengan konsep yang digunakan para ahli. Menurut (Notoatmodjo, 2007), perubahan perilaku dikelompokan menjadi tiga:

a. Perubahan alamiah; Perilaku manusia selalu berubah, dimana sebagian perubahan diakibatkan kejadian alamiah. Apabila dalam masyarakat sekitar terjadi suatu perubahan lingkungan fisik atau sosial budaya serta ekonomi, maka anggota masyarakat di dalamnya juga akan mengalami perubahan.

b. Perubahan terencana; Perubahan perilaku ini terjadi karena dirancang sendiri oleh subyek.

c. Kesediaan untuk berubah; Apabila terjadi suatu inovasi atau program pembangunan di dalam masyarakat, maka yang sering terjadi iaah sebagian orang sangat cepat untuk menerima inovasi atau perubahan tersebut (berubah perilakunya, serta sebagian yang lain begitu lambat daam menerima inovasi serta perubahan tersebut. Hal ini diakibatkan setiap orang memiliki untuk berubah yang berbeda-beda meskipun sama kondisinya.

Jelas sekali pola strategi komunikasi yang diterapkan tentukan akan merubah perilaku seseorang melalui perilaku dengan sebuah perubahan, Inilah yang dilakukan orangtua di lingkungan RPTRA Malinjo Kecamatan Pasar Minggu Jakarta Selatan.

Anak yang lahir dalam perkawinan adalah anak yang sah dan menjadi hak dan tanggung jawab kedua orang tua untuk memelihara dan mendidik dengan sebaik-baiknya sampai anak berumah tangga dan mandiri. Pada umumya pendidikan dalam rumah tangga bukan berpangkal dari kesadaran dan pengertian yang lahir dari pengetahuan mendidik, melainkan karena secara kodrati suasana dan strukturnya akan memberikan dan 
membangun situasi pendidikan yang alami. Situasi pendidikan itu terwujud berkat adanya pergaulan yang mempengaruhi secara timbal balik antara orang tua dan anak.

Menurut (Desminta, 2013) akan selalu timbul pertanyaan mengapa tindakan remaja yang jelas merugikan tetap dijalankan remaja. Dari hasil penelitian berlandaskan berbagai cara pendekatan dan pengamatan dapat disimpulkan bahwa faktor-faktor yang mempengaruhi proses perkembangan seorang individu dapat dibagi dalam dua kelompok utama:

1. Faktor-faktor di dalam diri individu sendiri meliputi faktor-faktor endogen yang terdiri dari komponen hereditas (keturunan) dan faktor konsistusi.

2. Faktor-faktor berasal dari luar individu tercakup dalam faktor lingkungan: faktor eksogen: terdiri dari berbagai komponen lingkungan, lingkungan keluarga, lingkungan sosial, lingkungan geografis dan fasilitas-fasilitas yang ada dalam lingkungan seperti makanan dan kesempatan/perangsangan belajar.

Banyak hal tindakan-tindakan yang diambil anak remaja akhirnya menimbulkan kerugian bagi diri sendiri, dan ada beberapa factor yang mempengaruhi dalam kehidupannya. Faktor itu dapat dating dari dalam dirinya sendiri atau factor lingkungan sekitar.

Menurut (Santrock, 2003) menyebutkan bahwa remaja adalah periode perkembangan di mana individu mendesak untuk mendapat otonomi dan berusaha untuk mengembangkan jati diri mereka. Perkembangan jati diri dan otonomi daerah dewasa adalah proses panjang, berlangsung paling cepat 10-15 tahun. Anak-anak yang patuh menjadi tidak patuh. Santrock juga menguraikan lebih jauh bahwa diantara perubahanperubahan pada remaja, yang dapat mempengaruhi hubungan orang-tua remaja adalah pubertas, penalaran logis yang berkembang, pemikiran idealis yang meningkat, harapan yang tidak tercapai, perubahan di sekolah, rekan sebaya, persahabatan, pacaran, dan pergerakan menuju kebebasan. Dari segi perubahan kognitif, remaja dapat memberikan alasan yang lebih logis pada orangtua daripada ketika masih kanak-kanak. Remaja memiliki rasa ingin tahu, seringkali secara mendetail. Misalnya, kenapa mereka mendapat hukuman. Ketika orangtua memberikan alasan yang masuk akal unguk menghukum mereka, kemajuan kognitif remaja dapat memberikan menemukan alasan dari keterangan tersebut.

Pendapat (Santrock, 2003) juga perlu dicermati, bahwa remaja yang lebih menunjukkan kepuasan terhadap bantuan yang diterima dari orang tua menunjukkan kesejahteraan emosi yang lebih baik. Selain itu remaja dengan hubungan yang aman dengan orangtua mempunyai harga diri yang lebih tinggi dan kesejahteraan emosi yang lebih baik.

Remaja dalam kehidupan sosialnya sangat tertarik kepada kelompok sebayanya sehingga tidak jarang orangtua dinomorduakan sedangkan kelompok di nomorsatukan. Segala hal yang diperbuat remaja ingin sama dengan kelompoknya, jika tidak sama akan merasa harga dirinya turun dan menjadi rendah diri. Uraian lebih jauh dikemukakan bahwa dalam kelompok remaja dapat memenuhi kebutuhannya, misalnya kebutuhan dimengerti, kebutuhan dianggap, kebutuhan diperhatikan, kebutuhan mencari pengalaman baru, kebutuhan berprestasi, kebutuhan diterima statusnya kebutuhan harga diri, kebutuhan rasa aman yang belum tentu diperoleh baik rumah maupun sekolahnya.

Hal lain yang sering muncul dalam hubungan orangtua dan remaja yaitu: potensi konflik yang akan timbul. Dikutip dari (Sholichah, 2016) mengatakan bahwa konflik yang timbul antara orangtua-remaja disebabkan remaja sedang berada pada masa penyesuaian dengan tuntutan lingkungannya yang baru dan lebih dari sekedar ingkungannya yang baru dan lebih dari sekedar lingkungan keluarga, sesungguhnya sedang membentuk citra diri yang memenuhi syarat untuk memasuki masa dewasa. Unsur-unsur yang mempengaruhi antar lain. Seperti perubahan jasmaniah, hubungan dengan orang tua, hubungan dengan teman seusia, perkembangan kognitif-intelektual dan identitas pribadi. 
Berkaitan penggunaan sosial media oleh remaja maka sosial media merupakan teknologi yang membantu memberikan kemudahan bagi remaja dalam memenuhi kebutuhannya. Kebutuhan akan kehadiran kelompok, meningkatkan interaksi dengan teman-teman, menjangkau harga diri, selain fungsi media sebagai alat untuk memperoleh informasi dan hiburan. Remaja di Ruang Publik Terpadu Ramah Anak yang biasa disebut RPTRA Malinjo Pasar Minggu Jakarta Selatan, merupakan wadah yang cukup memadai bagi anak-anak dalam bermain, belajar, diskusi dan melakukan berbagai kegiatan olahraga seperti basket, futsal, membuat prakarya sekolah, latihan tari dan drama. Tepatnya RPTRA ini ada di Jl,. Malinjo N0. 107, Rt7/RW 6, Pejaten Barat, Kecamatan Pasar Minggu, Jakarta Selatan.

Menurut Nurhartati selaku Ketua RPTRA Malinjo Pasar Minggu Jakarta Selatan, tentu saja, anak remaja yang ada di RPTRA Malinjo Pasar Minggu adalah anak di lingkungan sekitar Kelurahan Pejaten Barat dan juga dari sekolah yang terdekat seperti SMP 107 Jakarta dan SMK 8 Jakarta. Jumlah anak remaja yang ada di RPTRA Malinjo seluruhnya hampir 120 orang, meskipun tidak semua aktif karena kesibukan kegiatan sekolah. Namun, setiap harinya RPTRA tidak pernah sepi dengan anak-anak remaja yang datang. Misalnya, latihan Paskibraka atau pramuka, bahkan setiap Hari Senin dan Rabu malam digunakan latihan karate. Beliau juga menambahkan bawa di RPTRA Malinjo terbentuk juga Forum Anak RPTRA Malinjo, hanya karena kesibukan masing-masing anak dengan kegiatan sekolah maka kegiatan ini tidak berjalan sesuai harapan.

Adanya RPTRA ini sangat mendukung sekali sehingga anak-anak juga tidak kecanduan gadget. Selama ini banyak orangtua resah dengan tumbuh kembang anak-anak, zaman yang serba teknologi anak-anak cenderung tidak mau berinteraksi dan sibuk bermain dengan gadgetnya (Sumber: Nisya; Informan 2019).

Sejak dibangun RPTRA Malinjo Kecamatan Pasar Minggu Kelurahan Pejaten Barat, anak-anak di sekitar taman mau bermain di luar rumah dan mulai tidak kecanduan dengan gadget yang asyik dengan game. Sehingga mereka semakin banyak berinteraksi satu satu dengan yang lainnya. Fasilitas untuk anak pun cukup lengkap mulai dengan alatalat bermain sampai perpustakaan. Kegiatan-kegiatan yang ditawarkan pengelola sangat beragam sehingga anak-anak bebas mengikuti kegiatan apa yang menjadi minatnya. Alhasih, terjadi banyak perubahan dalam diri anak-anak di daerah malinjo yaitu mereka semakin ceria dan percaya diri dan bisa memecahkan masalah yang anak-anak hadapo.

Menurut pendapat para orangtua tempat RPTRA di Jakarta merupakan tempat yang cocok buat anak-anak bermain, berkumpul atau diskusi serta beraktivitas bersama. RPTRA Malinjo sangat bermanfaat sekali, sebagai sarana bermain untuk anak-anak, dengan kondisi Jakarta yang semakin sedikit tanah lapang untuk bermain anak. Sehingga harapan ke depannya Pemerintah DKI menambah jumlah RPTRA baru bahkan disetiap kota diharapkan akan adanya RPTRA.

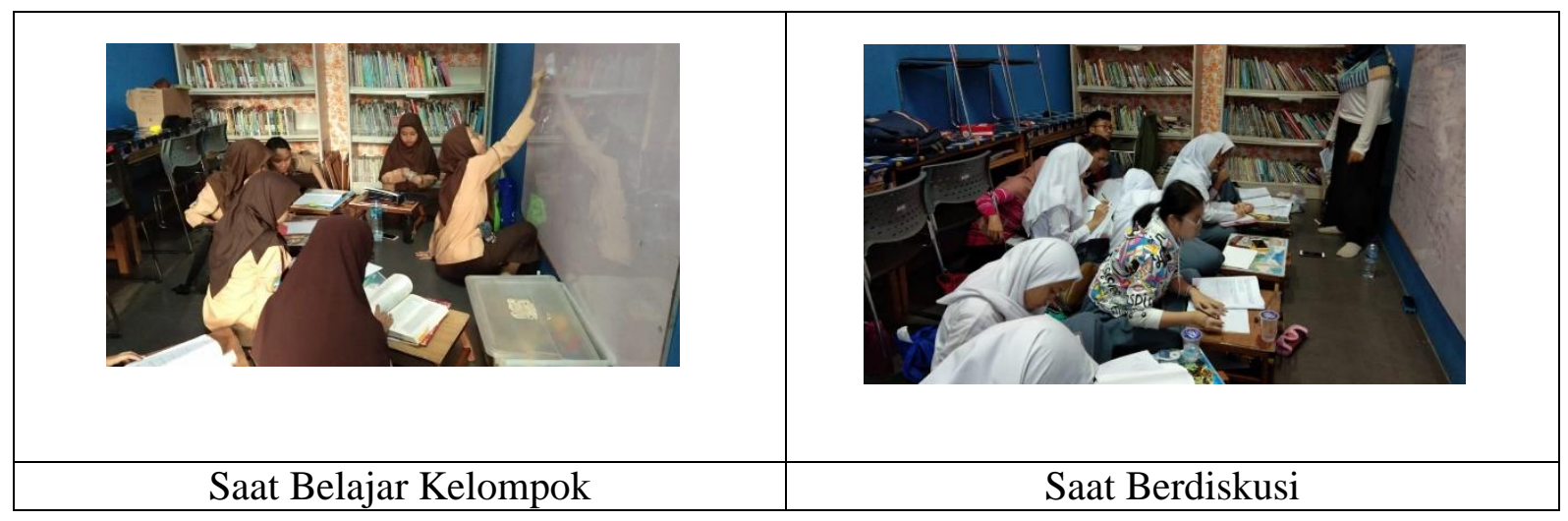




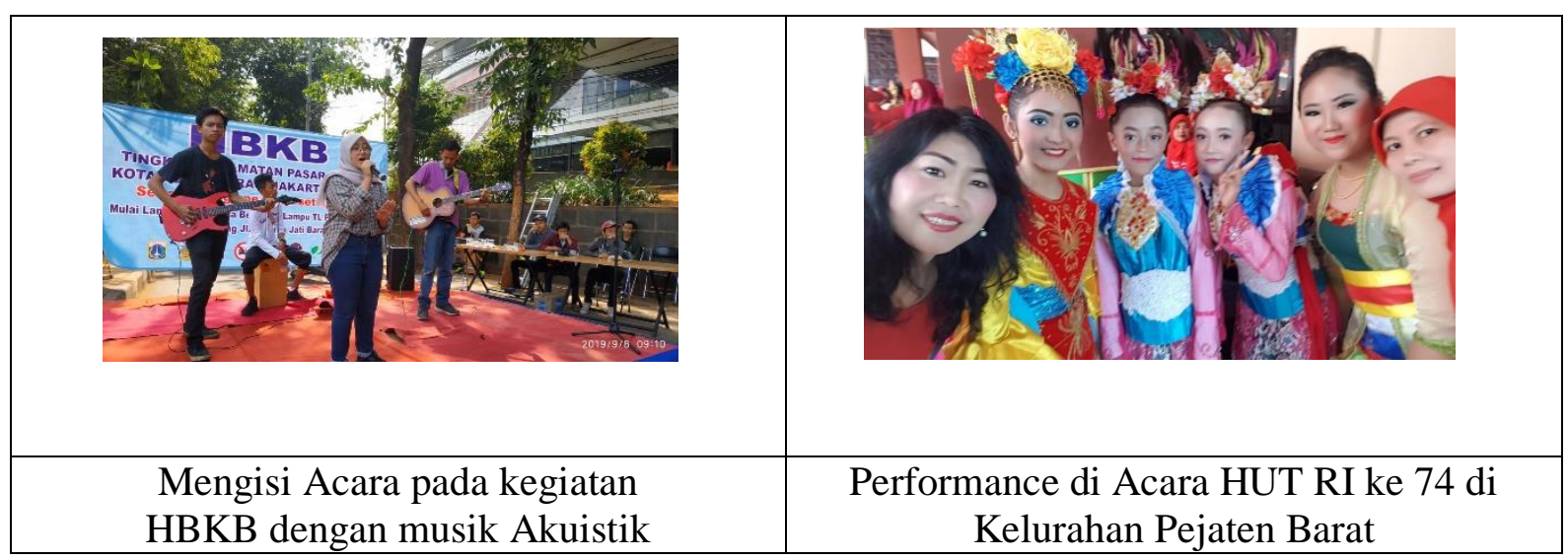

Komunikasi merupakan pertemuan paling sedikit dua orang yang bertujuan untuk memberikan pesan dan informasi secara langsung, sehingga pola strategi komunikasi yang dilakukan orangtua terhadap anak remaja yaitu: Pertama, Perubahan alamiah, perilaku remaja yang berubah, dimana sebagian perubahan disebabkan kejadian alamiah. Apabila dalam masyarakat sekitar terjadi suatu perubahan lingkungan fisik atau sosial budaya dan ekonomi, maka anggota masyarakat di dalamnya juga akan mengalami perubahan. Ini terlihat pada anak-anak di Malinjo Kelurahan Pejaten Barat, di mana biasanya para anak lebih sibuk dengan gadgetnya di rumah melalui game sekarang ini sejak berdirinya RPTRA Malinjo Kecamatan Pasar Minggu Kelurahan Pejaten Barat, anak-anak lebih memilih bermain di luar dari pada bermain gadget. (https://Republika.co.id Dampak di bangunnya RPTRA Malinjo anak-anak tak kecanduan gadget lagi 24 Juni 2019).

Bertemu dengan teman-teman yang sebaya mengalami suatu perubahan terlebih ketika memilki satu hobi yang sama. Secara alamiah perubahan terjadi pada remaja Malinjo Kecamatan Pasar Minggu. Bahwa adanya RPTRA ini menjadi tempat pertemuan yang efektif antar anak. Meskipun teknologi digital dapat digunakan dalam membangun anakanak belajar dan berkembang, penting bagi orangtua untuk memantau jenis informasi apa yang dapat diakses menggunakan gadget. Sangat dibutuhkan pengawasan dan control terhadap anak saat berinternet, para orangtua diharapkan dapat memberikan pengetahun, bimbingan serta pengarahan mengenal dunia teknologi. (Informan: Ibu Nurhartati)

Dari hasil diskusi RPTRA tersebut, beberapa peserta menceritakan penerapan teknik pola asuh demokrasi pada anak. Ibu sebagai teman anak, ibu menjadi orang yang bisa berkomunikasi dengan baik dalam mempertimbangkan kegiatan yang disukai anak meskipun itu berkaitan dengan media sosial. Orang tua dapat turut serta bermedia sosial dengan cerdas, menjelaskan dampak negatif bila informasi yang salah tidak disaring terlebih dahulu. Secara umum sebenarnya anak anak memiliki dasar perilaku yang baik, namum seiring dengan pengaruh perkembangan zaman, perkembangan teknologi dan kecepatan informasi saat ini memengaruhi mental dan budaya remaja. Oleh sebab itu, perlunya pendidikan yang tepat dan sesuai dengan tujuan dan harapan remaja akan tumbuh dengan sehat, cerdas dan memiliki kepekaan dan sosialitas pada dunia sekitar mereka atau gaya hidup bermasyarakat dengan mampu belajar dan berinovasi demi terciptanya remaja yang tangguh dan cerdas di era milenial saat ini.

Kedua; Perubahan terencana yaitu Perubahan perilaku ini terjadi karena direncanakan sendiri oleh subyek. Tidak hanya itu ada memang beberapa remaja yang tetap tidak mau terlalu aktif, namun itu tidak menjadi masalah. Biasanya remaja tersebut memang lebih banyak diam di dalam rumah tetapi jika diikutsertakan dalam kepanitiaan misalnya 17 Agustus, para remaja itu akan aktif melakukan kegiatan. Sejak berkembangnya game online kadang membuat anak lupa akan tugas dan kewajibannya, sehingga tidak jarang jika sudah berhadapan dengan game mereka hampir lupa dengan tugas dan makan. Sehingga pengawasan yang ketat dibutuhkan dari orangtua.

Kesediaan untuk berubah. Apabila terjadi suatu inovasi atau program pembangunan di dalam masyarakat, maka yang sering terjadi adalah sebagian orang sangat cepat untuk 
menerima inovasi atau perubahan tersebut. Perubahan perilaku pada remaja Malinjo memang ada yang cepat mampu melakukan dengan baik, namun ada juga perubahannya yang lambat. Perubahan perilaku pada anak remaja dalam komunikasi antar pribadi merupakan proses pertukaran informasi yang dianggap penting dan menjadi keharusan bagi setiap anak, baik secara formasl atau informal. Tidak seorang pun anak remaja tidak melakukan komunikasi dalam hidupnya, karena setiap orang akan berusaha menjalin dan membuka komunikasi dengan orang lain.

Beberapa faktor-faktor yang mempengaruhi proses perkembangan seorang anak remaja yaitu terkadang memang datang dalam diri remaja itu sendiri, mereka tidak merasa percaya diri kalau mereka memiliki kemampuan yang sama dengan teman mereka, sehingga kadang-kadang mereka lebih tertutup tidak terbuka. Selain itu faktor, keluarga yang terkadang orangtua tidak mendukung mereka bersosialisasi, lebih mengutamakan mereka belajar. Tanpa disadari orangtua saat ini anak-anak sudah memasuki masa Generasi $\mathrm{Z}$, dimana semuanya serba digital dan akses internet sangat mudah dijangkau. Dampak gadget telah merubah perilaku menjadi sesuatu dimana generasi $\mathrm{Z}$ menjadi suka yang instan dan viral. Gaya hidup atau sesuatu yang tranding diikuti menjadi panutan, tak peduli apakah berdampak positif atau negatif, Karena itu orangtua harus lebih bijak dalam penggunaan gadget.

\section{Kesimpulan}

Kehidupan dengan kecanggihan teknologi gadget seperti pisau bermata dua, manfaatnya sangat banyak, sekaligus risiko yang ditimbulkannya juga besar, berbahaya jika digunakan kurang bijaksana, untuk itu pola strategi komunikasi orang tua terhadap anak pada era digitalisasi dalam penelitian ini yaitu:

1. Para orangtua harus bisa memberitahu dengan pola strategi komunikasi bahwa dunia maya memiliki sisi negatif, sehingga anak-anak dibekali dengan membatasi waktu bermain gadget melalui mendorong anak-nak melakukan banyak aktivitas fisik di luar rumah, sehingga anak-anak tidak ketergantungan dengan gadget.

2. Bimbingan, perhatian, dan kasih sayang yang terjalin antara orang tua dengan anakanak, merupakan basis yang ampuh bagi pertumbuhan dan perkembangan psikis serta nilai-nilai sosial dan religius dalam diri anak. Melihat dari perkembangan era digital yang semakin berkembang di dunia saat ini yang tentunya berpengaruh terhadap perkembangan psikologi anak sehingga keluarga merupakan benteng utama dalam melakukan pendidikan yang baik dari efek buruk yang ditimbulkan dari perkembangan era digital tersebut.

3. Orang tua juga tidak boleh menutup rapat-rapat dari perkembangan era digital bagi anak dikarenakan dibalik perkembangan era digital tersebut ada banyak hal positif yang dapat diraih, pada titik inilah peran orang tua dalam mendidik anak dalam era digital sangat dibutuhkan guna memilah hal positif dan negatif dari perkembangan teknologi tersebut. Berdasarkan perkembangan teknologi yang ada saat ini, menjadikan kendala terberat bagi orang tua dalam mendidik anak-anaknya. Selain itu menciptakan suasana keluarga yang dekat dengan cara sering mengobrol, bermain dan mendengar curhatan anak-anak. Serta harus ada komitmen antar anggota keluarga dalam penggunaan gadget di era digitalisasi. Sangat diharapkan tempat seperti RPTRA di Jakarta metupakan tempat yang cocok buat anak-anak bermain, berkumpul atau diskusi serta beraktivitas bersama.

4. Organisasi RPTRA Malinjo sangat bermanfaat sekali, sebagai sarana bermain untuk anak-anak, dengan kondisi Jakarta yang semakin sedikit tanah lapang untuk bermain anak. Sehingga harapan ke depannya Pemerintah DKI menambah jumlah RPTRARPTRA yang baru. Sejak dibangun RPTRA Malinjo Kecamatan Pasar Minggu Kelurahan Pejaten Barat, anak-anak di sekitar taman itu mau bermain di luar rumah dan mulai tidak kecanduan dengan gadget dengan asyik game yang dimainkannya. 
Sehingga mereka semakin banyak berinteraksi satu satu dengan yang lainnya. Fasilitas untuk anak pun cukup lengkap mulai dengan alat-alat bermain sampai perpustakaan. Kegiatan-kegiatan yang ditawarkan pengelola sangat beragam sehingga anak-anak bebas mengikuti kegiatan apa yang menjadi minatnya. Maka, terjadi banyak perubahan dalam diri anak-anak di daerah Malinjo yaitu mereka semakin ceria dan percaya diri dan bisa memecahkan masalah yang anak-anak hadapi. 


\section{BIBLIOGRAFI}

Bogdan, R., \& Taylor, S. (1992). Pengantar Metode Kualitatif. Surabaya: Usaha Nasional.

Cholik, C. A. (2017). Pemanfaatan Teknologi Informasi Dan Komunikasi Untuk Meningkatkan Pendidikan Di Indonesia. Syntax Literate; Jurnal Ilmiah Indonesia, 2(6), 21-30.

Desminta. (2013). Psikologi perkembangan peserta didik: Panduan bagi orang tua dan guru dalam memahami psikologi anak usia SD, SMP, dan SMA. PT. Remaja Rosdakarya.

Ihsan, F. (2005). Dasar-dasar Pendidikan (Cet. IV). PT Rineka Cipta.

Kriyantono, R., \& Komunikasi, T. P. R. (2010). Jakarta. Kencana Prenada Media Group.

Moleong, L. J. (2007). Metodologi penelitian kualitatif edisi revisi. Bandung: PT Remaja Rosdakarya, 103.

Narbuko, C., \& Achmadi, A. (2005). Metodologi Penelitian, cet. VI (Jakarta: PT. BumiAksara.

Notoatmodjo, S. (2007). Promosi kesehatan dan ilmu perilaku.

Rakhmat, J., \& Surjaman, T. (2012). Metode penelitian komunikasi: dilengkapi contoh analisis statistik. Remaja Rosdakarya.

Ramadhani, S. P., \& Ritonga, R. (2019). Sosialisasi Peran Orangtua Terhadap Perkembangan Anak Di Era Digital Madrasah Ibtidayah Gunung Bunder II, Pamijahan Jawa Barat. Jurnal Pengabdian Masyarakat (JPM-IKP), 2(02), 94-100.

Santrock, J. W. (2003). Adolescence perkembangan remaja. Jakarta: Erlangga, 422-424.

Shin, Y.-J. (2014). Mendidik anak di era digital. Jakarta: PT Mizan Publika.

Sholichah, M. (2016). Pengaruh persepsi remaja tentang konflik antar orang tua dan resiliensi terhadap depresi dan kecemasan. Humanitas: Jurnal Psikologi Indonesia, $13(1), 22-36$.

Winarno, H. dan. (2012). Ilmu Sosial \& Budaya Dasar(Cet. VI). PT Bumi Aksara. 